\title{
UPDATES ON THE TREATMENT OF PTERYGIUM
}

Dusan Todorovic ${ }^{1}$, Tatjana Sarenac Vulovic ${ }^{2}$, Suncica Sreckovic ${ }^{2}$, Svetlana Jovanovic ${ }^{2}$, Katarina Janicijevic ${ }^{1}$, Zeljko Todorovic ${ }^{1}$

${ }^{1}$ Faculty of Medical Sciences, University of Kragujevac, Serbia

${ }^{2}$ Clinic of Ophthalmology, Clinical Center "Kragujevac", Serbia

\author{
NOVINE U LEČENJU PTERIGIJUMA

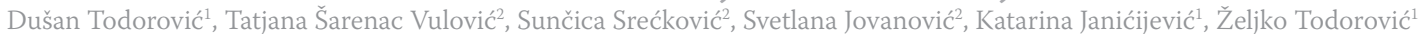 \\ ${ }^{1}$ Fakultet medicinskih nauka, Univerzitet u Kragujevcu, Srbija \\ ${ }^{2}$ Klinika za oftalmologiju, Klinički centar Kragujevac, Srbija
}

\begin{abstract}
Pterygium is an ocular disease characterised by the growth of fibrovascular conjunctiva on the cornea. It occurs more often in men, at an older age, and in individuals exposed to ultraviolet radiation. Surgical treatment is the primary treatment for pterygium and there are two common procedures for pterygium excision. In the first method, the head of the pterygium is separated from the corneal surface using a surgical blade. The second method is based on avulsion. Other approaches to excising the pterygium include the use of argon laser and excimer laser. Because of a high recurrence rate, adjuvant therapies, including radiotherapy, chemotherapy, and graft procedures, are used after pterygium excision. These procedures have become the standard long-term treatments for pterygium. Radiotherapy is based on beta irradiation. Chemotherapy includes the use of mitomycin C, 5-fluorouracil, bevacizumab, and loteprednol etabonate. Graft procedures include amniotic membrane grafts and conjunctival autografts. Many surgeons believe that using mitomycin $C$ and conjunctival autografts provides the best outcomes in terms of recurrence, cosmetics and patient satisfaction.
\end{abstract}

Keywords: pterygium, excision, adjuvant therapy, recurrence

\section{SAŽETAK}

Pterigijum je očno oboljenje i predstavlja rast fibrovaskularne konjunktive preko rožnjače. Češće se javlja kod muškog pola, starijih ljudi, kao i kod onih koji su izloženi utraljubičastom zračenju. Hiruški tretman predstavlja osnovni tretman pterigijuma. Postoje dve vodeće procedure za eksciziju pterigijuma. U prvoj metodi glava pterigijuma razdvaja se od površine rožnjače korišćenjem hiruškog noža. Druga metoda zasnovana je na avulziji. Drugi pristupi eksciziji pterigijuma uključuju argon laser i egzajmer laser. Zbog visoke stope recidiva, nakon eksizije pterigiju$m a$, koriste se adjuvantne terapije koje uključuju radioterapiju, hemoterapiju, procedure sa plasiranjem graftova. One su postale standardni modaliteti dugoročnog tretmana pterigijuma. Radioterapija je zasnovana na beta zračenju. Hemoterapija uključuje upotrebu Mitomicina C, 5-flurouracila, Bevacizumaba, Loteprendol etabonata. Procedure sa plasiranjem graftova su amnionski membranski graft $i$ konjunktivalni autograft. Mnogi hirurzi smatraju da upotreba Mitomicina C $i$ konjunktivalnog autografta daje najbolje ishode u smislu recidiva, kozmetskog izgleda $i$ zadovoljvstva pacijenta.

Ključne reči: pterigijum, ekscizija, adjuvantna tarapija, recidiv

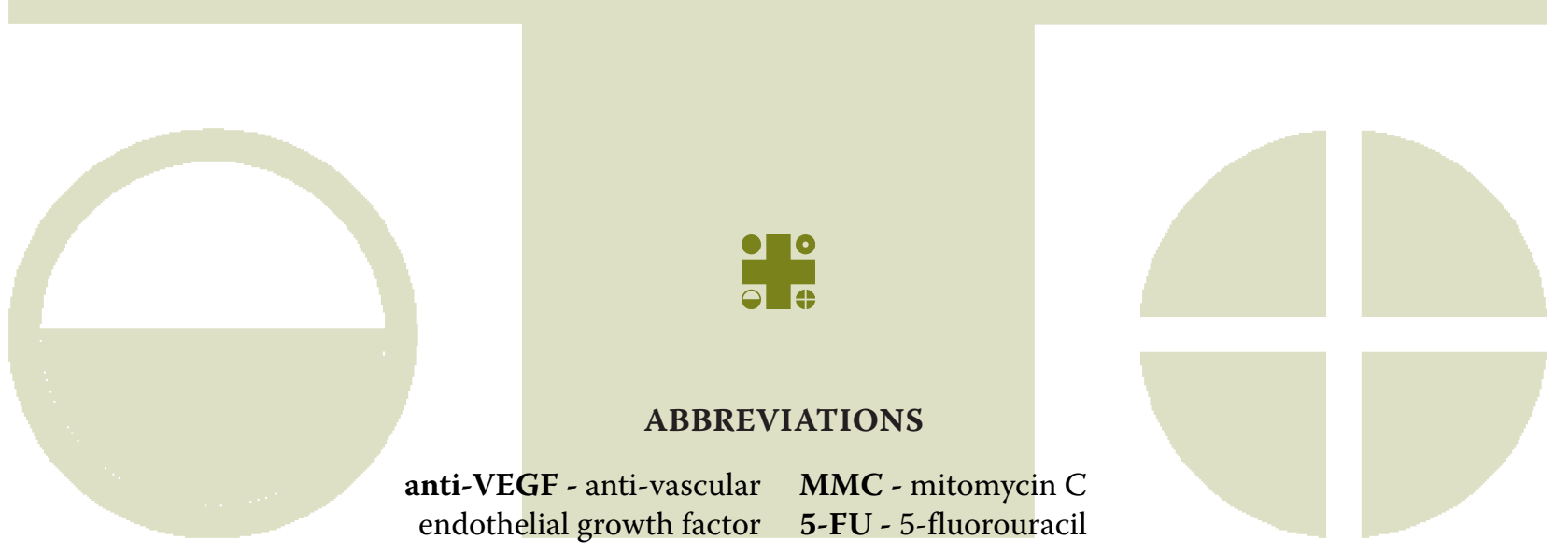

DE GRUYTER

UDK: 617.711-004.4 / Ser J Exp Clin Res 2016; 17 (3): 257-261 DOI: 10.1515/SJECR-2016-0012

Corresponding author: Dušan Todorović

phone number: +38163/175-05-14, Address: 26 Daničićeva Street, e-mail: drdusantodorovic@yahoo.com 


\section{INTRODUCTION}

The term "pterygium", which is a latinized version of the Greek term "pterygion", meaning "small wing", describes a wing-shaped growth of fibrovascular conjunctiva on the cornea that most commonly appears on the nasal side (Figure 1) (1). Its presence is not just a cosmetic issue, as it also indicates a clinical condition that affects vision by blocking the visual axis, causing tear film instability, or inducing corneal astigmatism (1). The prevalence rates vary widely, but they are generally more frequent in the equatorial belt and are associated with high levels of ultraviolet radiation, which is the most important etiological factor of pterygium occurrence (2). Earlier epidemiological studies indicated a higher prevalence in rural regions, with age and in men, which often correlates with outdoor work $(3,4)$.

Despite an extensive presence in the literature, pterygium still remains somewhat of an enigma. The first known authors who described pterygium and its surgical management were Hippocrates, Celsus, Pallus, Sushruta and Aetius (3). Even then, they recognised that its treatment was difficult, and the recurrence or loss of vision was almost certain (1). Until the 20th century, there were few improvements in the treatment and prevention of pterygium recurrence. In fact, some treatment success was achieved only by introducing new drugs and methods (1).

\section{PTERYGIUM EXCISION}

Surgical treatment remains the primary treatment for pterygium. Simple excision combined with adjuvant therapy, such as anti-VEGF agents, or grafts that include amniotic membrane grafts or conjunctival autografts provide the best results for the long-term success of pterygium surgery $(5,6)$.

The main goal of surgical excision is to completely remove all parts of the pterygium head, neck and body (7).

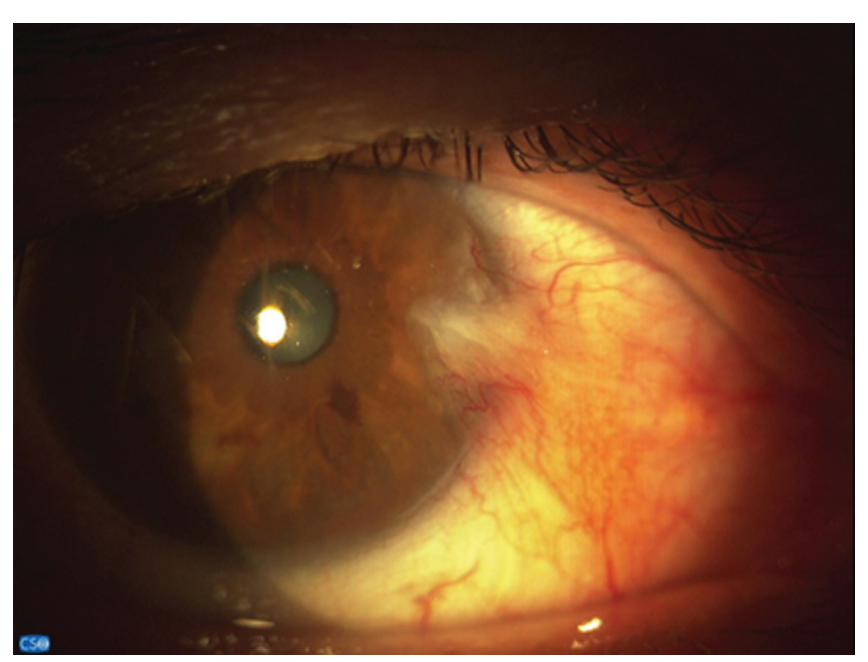

Figure 1. Pterygium- a wing-shaped growth of fibrovascular conjunctiva on to the cornea, most commonly on the nasal side.
There are two procedures that are frequently performed for pterygium excision. In the first method, after administering an appropriate local anaesthesia, the head of the pterygium is grasped with forceps and separated from the corneal surface using a surgical blade. The rest of the pterygium is dissected with scissors posteriorly up to approximately five to seven millimetres from the limbus and then cut (8). The second method is based on avulsion. Subsequent to undermining and dissecting below the body of the pterygium, an unsharpened instrument, such as a spatula, is inserted underneath the pterygium body. In the next step, the body of the pterygium is pulled with forceps, and the head is cut away from the cornea (8). The aim for both methods is a clear corneal bed. This is achieved by using a surgical blade to scrape off the remaining parts of the pterygium and by cauterisation any bleeding vessels (8).

Other approaches to excising the pterygium include argon laser and an excimer laser blade $(9,10)$. These methods are used after pterygium removal to achieve a fine corneal surface. In some conditions, these lasers can be used to completely excise the pterygium, but these procedures are usually associated with a higher risk of complications (10). Problems that can occur with pterygium excision are an inability to identify a good separation area during blunt dissection and pterygium tissue remnants on the cornea $(9,10)$. Applying ethanol before surgical excision can improve these techniques (11). Ethanol separates corneal epithelial cells by destroying their junctions, which makes it easier to remove the pterygium from the underlying cornea with a spatula. Additionally, prior ethanol application establishes a better separation area (11). This method is especially suitable for patients with recurrent pterygium in which the cornea has become thin or with a double-headed pterygium (11).

\section{ADJUVANT THERAPIES}

A high recurrence rate associated with the bare sclera technique led to the development of several procedures for managing pterygium after its excision (8). These include radiotherapy, chemotherapy and graft procedures (12). Even these procedures have some concerns regarding safety, patient comfort, surgery costs and duration, or whether the results of the surgical treatment are improved. These procedures have become standard for the long-term treatment of pterygium (12).

\section{BETA IRRADIATION}

Application of beta irradiation to the bare sclera, usually as a single dose, was shown to be an effective postoperative therapy, especially when it was applied just after pterygium surgery or within 24 hours (13). Additionally, beta irradiation can be combined with other adjuvant methods (14). Radiotherapy has become unpopular among surgeons because of previously documented complications that include conjunctival inflammation, scleral melting, cataract, and uveitis (15). 


\section{CHEMOTHERAPY}

Over the years, many substances have been used in attempts to prevent recurrence after pterygium excision. Triethylene thiophosphoramide (thiothepa) was one of the first known chemotherapeutic agents used for this purpose (16). Afterwards, other drugs were found to play a role in reducing the recurrence rate, which include doxorubicin and steroids, and more recently, alcohol and anti-VEGF $(17,18)$. In the last few years, it was reported that the level of VEGF in pterygium tissue was increased compared with the levels in the normal conjunctiva, which justified the use of anti-VEGF to treat pterygium (19).

It is well known that recurrent pterygium has a more aggressive form, which seems to be a strong motivator for investigators to find an adequate adjuvant treatment to prevent pterygium regrowth (8). Many anti-VEGF drugs have been used for this purpose worldwide, but mitomycin $\mathrm{C}$ and 5-fluorouracil are the most popular (20).

\section{MITOMYCIN C}

MMC is a natural antibiotic-antineoplastic compound derived from Streptomyces caespitosus (21). It is an alkylating agent, rather than an antimetabolite, that selectively inhibits DNA replication, mitosis and protein synthesis. MMC inhibits proliferation of fibroblasts and suppresses vascular ingrowths (21). The first known use of MMC in pterygium management was described in 1963 (22). Two approaches have been developed for applying mitomycin $\mathrm{C}$, which include postoperative use of topical eye drops and intraoperative use of sponges soaked in $0.02 \%$ mitomycin $\mathrm{C}$ (dose, $0.2 \mathrm{mg} / \mathrm{ml}$ ) applied directly to the bare sclera for three to five minutes (23). This could be used as a primary adjuvant treatment, or an additional graft of conjunctiva or amniotic membrane could be used to cover the bare sclera (24). However, adjuvant mitomycin C treatment is not without risk. It is associated with prolonged, irreversible stem cell damage that can lead to chronic keratopathy and toxic keratoconjunctivitis (21). It can also cause aseptic scleral necrosis, infectious sclerokeratitis, and secondary glaucoma (23). An important fact to remember when using $\mathrm{MMC}$ is to be aware of complications as they arise, which can occur many months after MMC application (22). It is recommended to use MMC intraoperatively more than postoperatively because of better control over the dose. Overdose is not uncommon in the postoperative period when mitomycin $C$ is prescribed to the patient (20).

\section{5-FLUOROURACIL}

5-FU, a pyrimidine analogue, inhibits DNA synthesis (25). Its effect is expressed in S phase of the cell cycle (25). It also blocks proliferating fibroblast cells that are activated in response to inflammation (25). As previously mentioned for MMC, 5-FU can be applied as a single adjuvant therapy, or it can be combined with a grafting procedure after pterygium excision (20). 5-FU use is related to a few transient complications, but there is still no common opinion among investigators as to how the long-term safety and efficacy of 5-FU application can be adequately evaluated in pterygium treatment (23).

\section{BEVACIZUMAB}

Bevacizumab is a recombinant humanised murine monoclonal immunoglobulin G1 that inhibits the VEGF-A isoform, the main stimulator of angiogenesis (26). Significant regression of limbal-conjunctival neovascularisation and a delayed recurrence were reported in patients with recurrent pterygium who were treated with bevacizumab (26). Intraoperatively, bevacizumab is often used as a subconjunctival injection, disabling neovascularisation of the cornea and conjunctiva (27). This method of bevacizumab administration can be performed alone or in combination with argon laser phototherapy to obliterate specific conjunctival feeder vessels (27). Bevacizumab applied topically can prevent corneal neovascularisation $(28,29)$.

\section{LOTEPREDNOL ETABONATE}

An improved understanding of the roles that inflammation plays in the pathogenesis and surgery for pterygium in recent years has led to the use of topical corticosteroids, such as loteprednol etabonate, in pterygium management protocols (30). Compared with other corticosteroids, loteprednol etabonate has a unique structure, which allows it to readily penetrate cell membranes (31). In addition, it has a strong potential for glucocorticoid receptors, whereas the detached drug is rapidly converted into inactive metabolites, preventing any unwanted side-effects of ocular corticosteroids, such as intraocular pressure elevation and cataractogenesis (32). Currently, there are no significant clinical trials that have revealed positive correlations between loteprednol etabonate use and a reduction in the recurrence of pterygium, which leaves possibilities for future investigators (33).

\section{GRAFT PROCEDURES}

Amniotic membrane graft and conjunctival autograft have become standard pterygium treatments for many surgeons (23). After pterygium excision, these grafts can be implemented alone or combined with other adjuvant therapies. The currently preferred method for graft procedures is to attach the graft with fibrin glue rather than sutures because of its superior intraoperative and postoperative characteristics (34). These advantages include reductions in the operation time, postoperative inflammation and recurrence rate (35) 


\section{AMNIOTIC MEMBRANE GRAFT}

The first documented usage of the amniotic membrane graft is connected to its original description in 1947 (1). The amniotic membrane is composed of three different layers: an epithelial layer, basement membrane and an avascular stroma (36). Its useful characteristics include anti-inflammatory, antiscarring, and anti-angiogenic properties, which make amniotic membranes compatible for pterygium treatment. The amniotic membrane can be applied when it is fresh or cryopreserved. In developing countries, fresh amniotic membrane is usually unavailable because of the need to test it in many types of infections (23). It serves as an alternative to conjunctival tissue in cases where there is a large conjunctival defect and to cover the bare sclera. The amniotic membrane has no human leucocyte antigens, so it has no risk of rejection (36). The advantages of amniotic membrane transplantation over other grafting procedures are a shorter surgical time, less eye pain, faster recovery, and usually better cosmetic outcomes (37).

\section{CONJUNCTIVAL AUTOGRAFT}

For the last thirty years, since its first introduction by Kenyon et al. (38) conjunctival autograft has become probably the most effective treatment for pterygium due to the transplantation of autologous tissue. Covering the bare sclera could be done by a primary direct closure, a sliding conjunctival flap, or by a free conjunctival autograft that is usually taken from the superior bulbar conjunctiva (39). It was shown that sliding and free grafts are more effective than direct conjunctival closure (39). The reported recurrence after this procedure is $0-39 \%(40)$. The recurrence rate can be decreased by the application of fibrin glue or alcohol while performing pterygium excision and by subsequently covering the bare sclera with conjunctival autograft (34). Minimal use of cautery, ensuring the graft is tendon free, and removal of excess fibrin are important factors for successful conjunctival graft transplantation (39). Limbal-conjunctival grafts, which include about two millimetres of limbal tissue in graft, allows for the damaged limbal cells to be filled with fresh tissue, which minimises the tendency for recurrence (41).

\section{CONCLUSION}

Direct comparisons among studies remain difficult because of the differences in the techniques of pterygium excision, durations and types of adjuvant therapies used. It is accepted that various adjuvant therapies and their combinations have significantly improved treatment outcomes in terms of recurrence, cosmetics and patient satisfaction. Many surgeons believe that using the mitomycin $\mathrm{C}$ and conjunctival autograft techniques provides the most satisfactory results (42). Other anti-VEGF agents, steroids and ethanol will probably further improve pterygium surgery when several clinical trials are finished.

\section{REFERENCES}

1. Johnson RD, Pai VC, Hoft RH. (2012). Historical approaches to pterygium surgery, including bare sclera and adjunctive beta radiation techniques. In: Hovanesian JA, editor. Pterygium: Techniques and Technologies for Surgical Success. Thorofare, NJ: Slack Incorporated: $27-36$.

2. Luthra R, Nemesure B, Wu S, Xie S, Leske M. (2001). Frequency and risk factors for pterygiumin the Barbados Eye Study. Arch Ophthalmol.119:1827-32

3. Cameron M. (1965). Pterygium Throughout the World. Edited by Thomas CC. Illinois: Springfield.

4. Vojnikovic B, Njiric S, Cocklo M, Toth I, Spanjol J, Marinovic M. (2007). Sunlight and incidence of pterigium on Croatian Island Rab: epidemiological study. Coll Antropol, 31:61-2.

5. K. R. Kenyon, M. D. Wagoner, and M. E. Hettinger. (1985). Conjunctival autograft transplantation for advanced and recurrent pterygium. Ophthalmology. vol. 92, no. 11, pp. 1461-70.

6. J. Cano-Parra, M. Diaz-Liopis, M. J. Maldonado, E. Vila, and J. L. Menezo. (1995). Prospective trial of intraoperative mitomycin $C$ in the treatment of primary pterygium. British Journal of Ophthalmology. vol. 79, no. 5, pp. 439-41.

7. Abiose A. (1997). Treatment of pterygium in Lagos, Nigeria. E Afr Med J. 54:327-31.

8. Alpay A, Ugurbas SH, Erdogan B. (2009). Comparing techniques for pterygium surgery. Clin Ophthalmol. 3:69-74.

9. Apaydin KC, Duranoglu Y, Saka O, Demirbas N. (2002). Argon laser treatment of pterygium. Ann Ophthalmol. 34:26-9.

10. Krag S, Ehlers N. Excimer laser treatment of pterygium. (2009). Acta Ophthalmologica. 70:530-3.

11. Chen KH, Hsu WM. (2006). Intraoperative ethanol treatment as an adjuvant therapy of pterygium excision. Int J Biomed Sci. 2:413-20

12. Kaufman SC, Jacobs DS, Lee WB, Deng SX, Rosenblatt MI, Shtein RM. (2013). Options and adjuvants in surgery for pterygium: a report by the American Academy of Ophthalmology. Ophthalmology. 120(1):201-8.

13. Jurgenliemk-Schulz IM, Hartman LJ, Roesink JM, Tersteeg RJ, Van der Tweel, Kal HB, et al. (2004). Prevention of pterygium recurrence by postoperative single dose beta irradiation: A prospective randomized clinical double blind trial. Int J Rad Oncol. 59:1138-47.

14. Ajayi BG, Bekibele CO. (2002). Evaluation of the effectiveness of postoperative beta irradiation in the management of pterygium. Afr J Med Med Sci. 31:9-11.

15. Walter WL. (1994). Another look at pterygium surgery with postoperative beta radiation. Ophthal Plast Reconstr Surg. Dec; 10(4):247-52.

16. Chapman-Smith JS. (1992). Pterygium treatment with triethylene thiophosphoramide. Aust NZJ Ophthalmol. 20:129-31 
17. Sodhi PK, Verma L, Pandey RM, Ratan S. (2004). Comparison between the role of intraoperative mitomycin $\mathrm{C}$ and doxorubicin in preventing the recurrence of primary pterygium. Ophthalmic Res. 37:1-6.

18. Wu PC, Kuo HK, Tai MH, Shin SJ. (2009). Topical bevacizumab eyedrops for limbal-conjunctival neovascularization in impending recurrent pterygium. Cornea. 28:103-4

19. Detorakis ET, Zaravinos A, Spandidos DA. (2010). Growth factor expression in ophthalmic pterygia and normal conjunctiva. Int J Mol Med. 25:513-6.

20. Alyaà Abood Kareem, Qasim Kadhim Farhood, Hussein Ali Alhammami. (2012). The use of antimetabolites as adjunctive therapy in the surgical treatment of pterygium. Clinical Ophthalmology. 6 1849-54.

21. Sutphin JE. (2008). Basic and Clinical Science Course: External disease and cornea. San Francisco:American Academy of Ophthalmology. 8: 394, 429-32.

22. Almond MC, Dastrup BT, Kaufman SC. (2012). 5-fluorouracil and mitomycin-C: adjuncts to pterygium surgery. In: Hovanesian JA, editor. Pterygium: Techniques and Technologies for Surgical Success. Thorofare, NJ: Slack Incorporated. 55-64.

23. Ang LP, Chua JL, Tan DT. (2007). Current concepts and techniques in pterygium treatment. Curr Opin Ophthalmol. 18:308-13.

24. de la Hoz F, Montero JA, Alio JL, Javaloy J, Ruiz-Moreno JM, Sala E. (2008). Efficacy of mitomycin C associated with direct conjunctival closure and sliding conjunctival graftfor pterygium surgery. Br J Ophthalmol. 92:175-8.

25. Brazowski E, Eytan K, Eisenthal A. (2007). In vitro modulation of interleukin-2-mediated human peripheral mononuclear cell proliferation and antitumor cytotoxicity by 5-fluorouracil. Anticancer Res. 27(6B): 4135-41.

26. Wu PC, Kuo HK, Tai MH, Shin SJ. (2009). Topical bevacizumab eye drops for limbal conjunctival neovascularization in impending recurrent pterygium. Cornea. 28(1):103-4.

27. Lekhanont K, Patarakittam T, Thongphiew P, Suwanapichon O, Hanutsaha P. (2012). Randomized controlled trial of subconjunctival bevacizumab injection in impending recurrent Pterygium: a pilot study. Cornea. 31(12):155-61.

28. Koenig Y, Bock F, Horn F, Kruse F, Straub K, Cursiefen C. (2009). Short and long-term safety profile and efficacy of topical bevacizumab (Avastin) eye drops against corneal neovascularization. Graefes Arch Clin Exp Ophthalmol. Oct, 247(10):1375-82.

29. K. Jae, K.Dong, K. Eun-Soon, J. K. Myoung, and T. Hungwon. (2013). Topically administered bevacizumab had longer standing antiangiogenic effect than subconjunctivally injected bevacizumab in rat corneal neovascularization. International Journal of Ophthalmology, vol. 6, no. 5, pp. 588-91.
30. Comstock TL, Decory HH. (2012). Advances in corticosteroid therapy for ocular inflammation: loteprednol etabonate. Int J Inflam. 2012:789623. doi: 10.1155/2012/789623.

31. Alberth M, Wu WM, Winwood D, Bodor N. (1991). Lipophilicity, solubility and permeability of loteprednol etabonate: a novel, soft anti-inflammatory steroid. J Biopharm Sci. 2(2):115-25.

32. Wu WM, Huang F, Lee Y, Buchwald P, Bodor N. (2008). Pharmacokinetics of the sequential metabolites of loteprednol etabonate in rats. J Pharm Pharmacol. 60(3):291-7.

33. Nguyen HT, Samudre SS, Lattanzio FA, Williams PB, Sheppard JD. (2008). Loteprednol etablonate reduces Inflammatory Response associated with Pterygium Progression. Investig Ophthalmol Vis Sci 49: 6027.

34. Karalezli A, Kucukerdonmez C, Akova YA, Yaycioglu RA, Borazan M. (2008). Fibrin glue versus sutures for conjunctival autografting in pterygium surgery: A Prospective comparative study. Br J Ophthalmol. 92:1206-10.

35. Srinivasan S, Dollin M, McAllum P, Berger Y, Rootman DS, Slomovic AR. (2009). Fibrin glue versus sutures for attaching the conjunctival autograft in pterygium surgery: A prospective observer masked clinical trial. Br J Ophthalmol. 93:215-8.

36. Cho H, Chuck RS. (2012). Pterygium excision and placement of amniotic membrane grafts. In: Hovanesian JA, editor. Pterygium: Techniques and Technologies for Surgical Success. Thorofare, NJ: Slack Incorporated. 91-100.

37. Tananuvat N, Martin T. (2004). The results of amniotic membrane transplantation for primary pterygium compared with conjunctival autograft. Cornea. 23:458-63.

38. Kenyon KR, Wagoner MD, Hettinger ME. (1985). Conjunctival autograft transplantation for advanced and recurrent pterygium. Ophthalmology. 92:1461-70

39. Kavita Mallikarjun Salagar, Kalyanappa Gurlingappa Biradar. (2013). Conjunctival Autograft in Primary and Recurrent Pterygium. Journal of Clinical and Diagnostic Research. Dec, Vol-7(12): 2825-7.

40. Koranyi G, Artzen D, Seregard S, Kopp ED. (2012). Intraoperative mitomycin $\mathrm{C}$ versus autologous conjunctival autograft in surgery of primary pterygium with 4 year follow up. Acta Ophthalmol. May;90(3):266-70.

41. Abdallah WM. (2009). Efficacy of limbal-conjunctival autograft surgery with stem cells in pterygium treatment. Mid E Afr J Ophthalmol. 16:260-2.

42. Katircioglu YA, Altiparmak UE, Duman S. (2007). Comparison of three methods for the treatment of pterygium: Amniotic membrane graft, conjunctival autograft and autograft plus mitomycin C. Orbit. 26:5-13. 


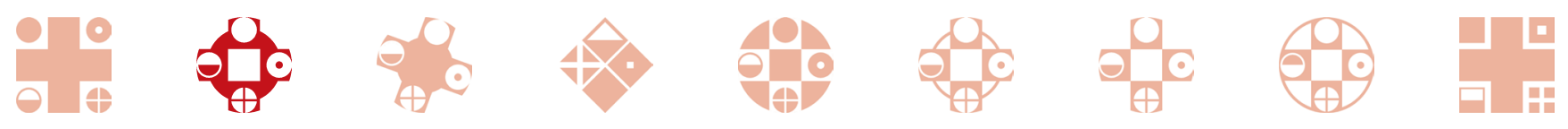

